\title{
深共融溶剂促进的亨利-傅克烷基化串联反应
}

\author{
胡智宇姜国芳* 祝志强龚伯桢谢宗波乐长高* \\ (东华理工大学 江西省合成化学重点实验室 江西南昌 330013)
}

\begin{abstract}
摘要 在氯化锌和氯化胆碱组成的深共融溶剂中, 以芳香醛、硝基甲烷和 $N$-取代苯胺为原料, 建立了一种绿色的亨利傅克烷基化串联反应方法. 在该方法中, 醛先与硝基甲烷发生 Henry 反应，其产物再与富电子芳烃进行 Friedel-Crafts 烷基化反应. 该一锅法串联反应不需要额外添加催化剂, 在温和条件下就能以较高产率快速地合成一系列目标产物. 深共熔溶剂(氯化锌和氯化胆碱)廉价, 且可循环使用, 从而降低了合成成本.
\end{abstract} 关键词 深共融溶剂; 亨利反应; 傅克烷基化反应; 一锅法反应; 串联反应

\section{One-Pot Domino Henry-Friedel-Crafts Alkylation Reaction in Deep Eutectic Solvent}

\author{
Hu, Zhiyu \\ Jiang, Guofang* \\ Zhu, Zhiqiang \\ Gong, Bozhen \\ Xie, Zongbo \\ Le, Zhanggao* \\ (Jiangxi Province Key Laboratory of Synthetic Chemistry, East China University of Technology, Nanchang, Jiangxi 330013)
}

\begin{abstract}
A green multicomponent reaction between aldehydes, nitromethane and $N$-substituted anilines in deep eutectic solvent (DES) has been developed. In this reaction, aldehydes and nitromethane underwent Henry reaction, followed by a Friedel-Crafts alkylation reaction with electron-rich arenes. The desired products were formed quickly in excellent yields under mild conditions without the need of any additional catalysts. The deep eutectic solvent (zinc chloride and choline chloride) is cheap and recyclable, which reduces the synthesis cost.
\end{abstract}

Keywords deep eutectic solvent; Henry reaction; Friedel-Crafts reaction; one pot reaction; tandem reaction

\section{Introduction}

Friedel-Crafts (FC) alkylation is one of the most important methods for $\mathrm{C}-\mathrm{C}$ bond formation in organic chemistry. ${ }^{[1]}$ Arene derivatives such as substituted anilines, phenols, naphthols and heteroarenes such as indole, dihydroindole and pyrrole derivatives have been successfully used as nucleophiles in Friedel-Crafts reaction in order to obtain arene derivatives. On the other hands, the use of nitroalkenes as electrophiles has attracted significant interest in recent years. The activating effect of nitro group, as well as the versatility by which the nitro group can be transformed into other functional groups, makes these compounds as suitable building blocks for the synthesis of many interesting pharmaceutical compounds. ${ }^{[2]}$ For example, the versatile nitroalkanes can be transformed into a wide variety of active compounds such as $\alpha$-substituted ke- tones ${ }^{[3]}$ and biologically active 2 -arylethylamines, ${ }^{[4]}$ which are useful chiral building blocks in the protein kinase B $(\mathrm{PKB})$ inhibitor $^{[4 \mathrm{a}]}$ and telcagepant (Figure 1). ${ }^{[\mathrm{b}]}$<smiles>NC[C@@H](c1ccc(Cl)cc1)c1ccc(-c2cn[nH]c2)cc1</smiles>

PKB ibhibitor<smiles>[R]=C1CCC(c2cccc(F)c2F)CN(CC(F)(F)F)C1=O</smiles>

Telcagepant
Figure 1 Biologically active 2,2-bisarylethylamines

Multicomponent reactions (MCRs), owing to the obvious advantages of automatable procedure, atom economy, time-saving, inherent exploratory power and minimization

\footnotetext{
* Corresponding authors. E-mail: gfjiang@ecut.edu.cn; zhgle@ecit.cn

Received June 15, 2020; revised July 16, 2020; published online August 26, 2020.

Project supported by the National Natural Science Foundation of China (No. 11765002) and the Science and Technology Projects of Jiangxi Province (No. 20192BBH80012).

国家自然科学基金(No. 11765002)和江西省科技计划(No. 20192BBH80012)资助项目.
} 
of chemical waste, have attracted considerable attention for the preparation of biologically active compounds. ${ }^{[5]}$ Due to the various advantages of MCRs compared with conventional multi-step synthesis, MCRs play an important role in the development of drugs with complex structures, ${ }^{[6]}$ such as carbon-carbon bond formation reaction in the field of Friedel-Crafts alkylation. In 1978, Yonemitsu et al. ${ }^{[7]}$ firstly reported the successful multicomponent based synthesis of 3-substituted indoles with Meldrum's acid, aldehydes and different indoles. Nevertheless, most reports in this area are focused on relatively more reactive indole or pyrrole derivatives. There are only a few reports on the Friedel-Crafts reaction of $\mathrm{N}, \mathrm{N}$-dialkylaniline derivatives with unsaturated carbonyl compounds, ${ }^{[8]}$ especially for the electron-rich arenes. The only report in this area is the Friedel-Crafts alkylation of $N, N$-dialkylaniline derivatives with nitrostyrene, which have been reported by Halimehjani et $a l^{[9]}$ using heteropolyphosphotungstic acid as catalyst. A few years later, Tang and his colleagues ${ }^{[2 \mathrm{~b}]}$ promoted the reaction with a cleaner solvent, hexafluoro2-propanol (HFIP). However, all of them need additional steps to synthesize nitrostyrene. Consequently, the search for more efficient, simple, low cost and environmentally benign methods for the preparation of Friedel-Crafts alkylation product for electron-rich arenes remains a challenging task.

To the best of our knowledge, using deep eutectic solvents (DESs) as solvent will be an ideal methodology to solve this problem. DESs are green solvents/catalysts with unique properties and can be designed by changing the salt or hydrogen bond donor. ${ }^{[10]}$ Compared with conventional organic solvents, ${ }^{[11]}$ DESs have more advantages, such as negligible vapor pressure, non-flammability, good chemical and thermal stability, non-toxicity, biodegradability, recyclability and low price among others. ${ }^{[12]}$ Thus, DESs as a type of ionic liquids formed by mixing a typical ammonium halide salt and hydrogen bond donors or metal salts, have gained much attention in synthetic organic chemistry. ${ }^{[13]}$ For instance, DESs have been used as efficient catalyst in several reactions such as esterification, ${ }^{[14]}$ FriedelCrafts alkylation and acylation, ${ }^{[15]}$ isomerization, ${ }^{[16]}$ Fischer indolization, ${ }^{[17]}$ Knoevenagel condensation, ${ }^{[18]} \mathrm{C}\left(\mathrm{sp}^{3}\right)-$ $\mathrm{H}$ functionalization ${ }^{[19]}$ and etc. ${ }^{[20]}$

As part of our continual exploration into the synthetic applications of DESs, we report herein a novel domino Henry/Friedel-Crafts alkylation of aldehydes, nitromethane, and $N$-substituted anilines using DESs (zinc chloride and choline chloride $(\mathrm{ChCl})$ ) without any additives. To the best of our knowledge, this is the first report on such a multicomponent synthesis strategy.

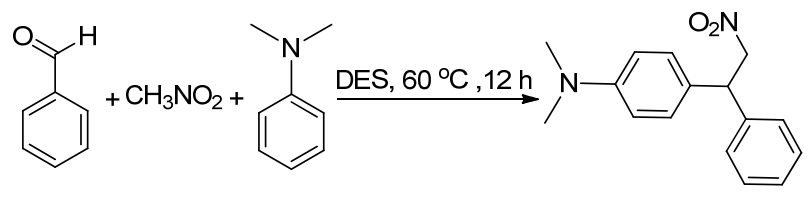

Scheme 1 Domino Henry-Friedel-Crafts alkylation reaction

\section{Results and discussion}

During the course of our initial investigation, the reaction between benzaldehyde (1a), nitromethane $\mathbf{2}$ and $\mathrm{N}, \mathrm{N}$-dimethylaniline (3a) was used as a model reaction (Table 1). Our study was started in the presence of different solvents. The control experiment in the absence of catalyst was first carried out. $\mathrm{H}_{2} \mathrm{O}$, ethanol, acetonitrile and dimethyl sulfoxide (DMSO) were selected as solvent for the reaction. Except for water, no desired product $\mathbf{4 a}$ was obtained (Table 1, Entries 1 4). This reaction does not work well in conventional organic solvents. Then, we considered using a new-type cleaning solvent for this reaction. When some DESs such as $[\mathrm{ChCl}][\mathrm{Urea}]_{2},[\mathrm{ChCl}][\mathrm{Glu}-$ cose $],[\mathrm{ChCl}][\mathrm{Glycerinum}]$ and $[\mathrm{ChCl}][\mathrm{Citric}$ acid] were tested as solvents, no desired product $\mathbf{4 a}$ was obtained (Table 1, Entries 5 8). But, to our delight, when [ChCl]$\left[\mathrm{ZnCl}_{2}\right]$ was applied as solvent, the desired product $\mathbf{4 a}$ was isolated in a good yield of $61 \%$ (Table 1, Entry 9). Meanwhile, the reaction did not afford the satisfactory yield when $[\mathrm{ChCl}]\left[\mathrm{ZnCl}_{2}\right]_{2}$ and $[\mathrm{ChCl}]\left[\mathrm{ZnCl}_{2}\right]_{3}$ were employed as solvents (Table 1, Entries 10,11). Therefore, [ChCl]$\left[\mathrm{ZnCl}_{2}\right]$ was chosen as our optimum solvent for the synthesis of $\mathbf{4 a}$.

Next, the model reaction was screened at different temperatures in $[\mathrm{ChCl}]\left[\mathrm{ZnCl}_{2}\right]$ as the solvent, without any additional catalysts. The product yield increased to $75 \%$ when the reaction was carried out in $[\mathrm{ChCl}]\left[\mathrm{ZnCl}_{2}\right]$ at $60{ }^{\circ} \mathrm{C}$ (Table 1, Entries 12, 13). Moreover, if the reaction time was extend to $12 \mathrm{~h}$, the yield increased to $80 \%$ (Table 1, Entry 14). The influence of the substrate molar ratio was also tested and $82 \%$ yield could be achieved with a molar ratio of $1: 3: 1(\mathbf{1 a}: \mathbf{2}: \mathbf{3 a})$. But considering the atomic economy, we still choose $1: 1: 1$ as the optimal molar ratio (Table 1, Entry 14). Finally, control experiments using different amounts of choline chloride or zinc chloride as catalyst in $\mathrm{H}_{2} \mathrm{O}$ were also tested. Very lower yields were obtained under these conditions (Table 1, Entries 15 18). The results (Table 1) demonstrated that $[\mathrm{ChCl}]\left[\mathrm{ZnCl}_{2}\right]$ was better than conventional organic solvents, or used as catalysts alone for this reaction.

After establishing the optimized reaction conditions, the generality of the reaction was evaluated by synthesizing a series of $N$-substituted anilines derivatives. As shown in Table 2, benzaldehydes bearing electron-withdrawing groups and electron-donating groups, including 4-nitrobenzaldehyde, 4-methylbenzaldehyde and so on, afforded the respective addition products $\mathbf{4 a} \sim \mathbf{4 g}$ in great yields of $77 \% \sim 83 \%$. It was noticed that aldehydes having electron-withdrawing group or electron-rich group at the para sites are not the main factors affecting the yield. Subsequently, the influence of substituents at the C(3) and C(2) position of the benzaldehydes was investigated. Such as 3-nitrobenzaldehyde and 2-nitrobenzaldehyde, gave the desiredproducts $4 \mathbf{h}(72 \%)$ and $\mathbf{4 i}(45 \%)$, respectively. Interestingly, the reaction also worked well with heterocyclic aldehydes, such as furfuraldehyde and thiophene 2-carb- 
Table 1 Optimization of the reaction condition ${ }^{a}$

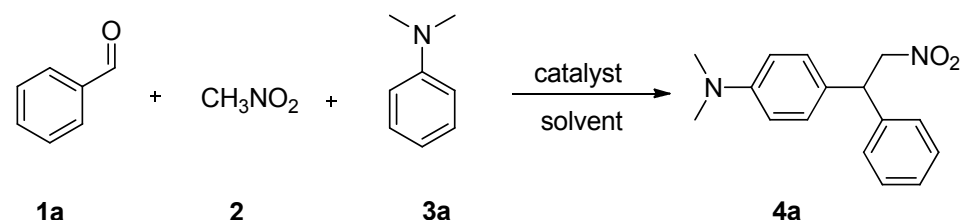

1a

3a

$4 a$

\begin{tabular}{|c|c|c|c|c|c|}
\hline Entry & Solvent & Catalyst & Temperature $/{ }^{\circ} \mathrm{C}$ & Time/h & Yield $^{b} / \%$ \\
\hline 1 & $\mathrm{H}_{2} \mathrm{O}$ & None & 80 & 8 & 6 \\
\hline 2 & $\mathrm{EtOH}$ & None & 80 & 8 & 0 \\
\hline 3 & $\mathrm{MeCN}$ & None & 80 & 8 & Trace \\
\hline 4 & DMSO & None & 80 & 8 & 0 \\
\hline 5 & {$[\mathrm{ChCl}][\mathrm{Urea}]_{2}$} & None & 80 & 8 & 0 \\
\hline 6 & {$[\mathrm{ChCl}][$ Glucose $]$} & None & 80 & 8 & 0 \\
\hline 7 & {$[\mathrm{ChCl}][$ Glycerinum $]$} & None & 80 & 8 & 0 \\
\hline 8 & {$[\mathrm{ChCl}][\mathrm{Citric}$ acid $]$} & None & 80 & 8 & 0 \\
\hline 9 & {$[\mathrm{ChCl}]\left[\mathrm{ZnCl}_{2}\right]$} & None & 80 & 8 & 61 \\
\hline 10 & {$[\mathrm{ChCl}]\left[\mathrm{ZnCl}_{2}\right]_{2}$} & None & 80 & 8 & 41 \\
\hline 11 & {$[\mathrm{ChCl}]\left[\mathrm{ZnCl}_{2}\right]_{3}$} & None & 80 & 8 & 20 \\
\hline 12 & {$[\mathrm{ChCl}]\left[\mathrm{ZnCl}_{2}\right]$} & None & 70 & 8 & 72 \\
\hline 13 & {$[\mathrm{ChCl}]\left[\mathrm{ZnCl}_{2}\right]$} & None & 60 & 8 & 75 \\
\hline 14 & {$[\mathrm{ChCl}]\left[\mathrm{ZnCl}_{2}\right]$} & None & 60 & 12 & $80\left(80^{c}, 82^{d}\right)$ \\
\hline 15 & $\mathrm{H}_{2} \mathrm{O}$ & $\mathrm{ChCl}(30 \mathrm{~mol} \%)$ & 60 & 12 & Trace \\
\hline 16 & $\mathrm{H}_{2} \mathrm{O}$ & $\mathrm{ZnCl}_{2}(30 \mathrm{~mol} \%)$ & 60 & 12 & 10 \\
\hline 17 & $\mathrm{H}_{2} \mathrm{O}$ & $\mathrm{ChCl}(2 \mathrm{mmol})$ & 60 & 12 & Trace \\
\hline 18 & $\mathrm{H}_{2} \mathrm{O}$ & $\mathrm{ZnCl}_{2}(2 \mathrm{mmol})$ & 60 & 12 & 17 \\
\hline 19 & None & $\mathrm{ChCl}(30 \mathrm{~mol} \%)$ & 60 & 12 & 0 \\
\hline 20 & None & $\mathrm{ZnCl}_{2}(30 \mathrm{~mol} \%)$ & 60 & 12 & 19 \\
\hline 21 & None & $\mathrm{ChCl}(2 \mathrm{mmol})$ & 60 & 12 & 0 \\
\hline 22 & None & $\mathrm{ZnCl}_{2}(2 \mathrm{mmol})$ & 60 & 12 & 8 \\
\hline
\end{tabular}

${ }^{a}$ Unless otherwise noted, reaction conditions: benzaldehyde $(0.2 \mathrm{mmol})$, nitromethane $(0.2 \mathrm{mmol})$ and $N, N$-dimethylaniline $(0.2 \mathrm{mmol})$ in $1 \mathrm{~mL}$ of solvent. ${ }^{b}$ Isolated yield after silica gel column chromatography. ${ }^{c}$ Yield in parenthesis corresponds to reaction conditions: benzaldehyde $(0.2 \mathrm{mmol})$, nitromethane $(0.3 \mathrm{mmol})$ and $N, N$-dimethylaniline $(0.2 \mathrm{mmol}) .{ }^{d}$ Yield in parenthesis corresponds to reaction conditions: benzaldehyde $(0.2 \mathrm{mmol})$, nitromethane $(0.6 \mathrm{mmol})$ and $N, N$-dimethylaniline $(0.2 \mathrm{mmol})$

aldehyde, providing the derivatives $\mathbf{4 j}(68 \%)$ and $\mathbf{4 k}$ (48\%). But 4-pyridinecarboxaldehyde (11) showed no reactivity under the same conditions, probably because of the lower electron density at the pyridine ring. Other tertiary anilines, such as $N, N$-diethyl aniline (3b) and $N$-methyl- $N$ phenylaniline $(\mathbf{3 c})$ were also efficient in these conditions to afford regioselectively only the para-alkylated products $\mathbf{4 m}$ and $\mathbf{4 n}$. On the other hand, the reaction with secondary anilines $\mathbf{3 d} \sim \mathbf{3 h}$ also underwent in a moderate to good yield $4 \mathbf{0} \sim 4 \mathbf{s}$. Besides, the electron-rich arene, 1,3,5trimethoxybenzene $\mathbf{3 i}$ reacted with benzaldehyde and nitromethane afford the corresponding alkylated product, the yield reached to $60 \%$ (Table 2 ).

In order to explore the mechanism of this reaction, several control experiments were performed (Scheme 2). In the first series experiments, benzaldehyde treated with nitromethane in the $[\mathrm{ChCl}]\left[\mathrm{ZnCl}_{2}\right]$ solvent gave Henry adduct 5 in yield of $30 \%$ after $6 \mathrm{~h}$. In the second experiments, benzaldehyde was treated with $\mathrm{N}, \mathrm{N}$-dimethylaniline under the same reaction conditions, and very few new material 6 was generated after $6 \mathrm{~h}$. Finally, the reaction of $N, N$ dimethylaniline and Henry adduct 5 gave the desired product $4 \mathrm{a}$ in a good yield of $63 \%$ in DES for $6 \mathrm{~h}$.

Based on the literature ${ }^{[16,21]}$ and control experiments, a plausible mechanism was proposed in Scheme 3. The DES catalyst is thought to play an important role in promoting nitroaldol reaction through $\left[\mathrm{ZnCl}_{3}\right]^{-}$ion to activate the aldehyde and nitromethane. Next, because of the presence of lewis acid $\left(\mathrm{ZnCl}_{2}\right)$, the 2-nitro-1-phenylethanol undergoes an the elimination reaction to obtain $\beta$-nitrosytrene. Then, we assume that DES activated the nitro group via $\left[\mathrm{ZnCl}_{3}\right]^{-}$ion and following by the nucleophilic attack of the $N, N$-dimethylaniline. The generated intermediate undergos the subsequent hydrogen transfer to afford the expected product $\mathbf{4 a}$.

The recovery and reusability of DES are necessary for economic and environmental aspects. Therefore, at the final step of this study, the operational stability (recycle-ability) of the $[\mathrm{ChCl}]\left[\mathrm{ZnCl}_{2}\right]$ was explored in the model reaction (benzaldehyde $(0.2 \mathrm{mmol})$, nitromethane $(0.2$ mmol) and $N, N$-dimethylaniline $(0.2 \mathrm{mmol}))$. After the completion of the model reaction, ethyl acetate and water were added to the reaction mixture for extraction as desired product. DES was recovered with evaporation process of 
Table 2 Substrate scope of the reaction ${ }^{a}$

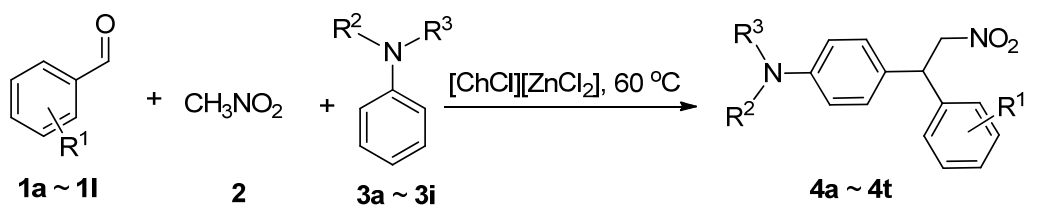

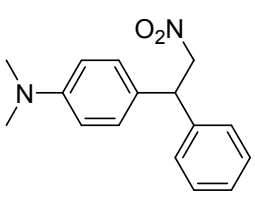

4a, 12 h, $80 \%$<smiles>CN(C)c1ccc(C(CN=O)c2ccccc2)cc1</smiles>

4f, 12 h, $80 \%$

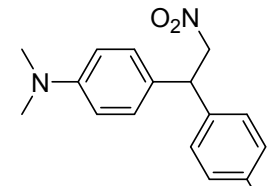

4b, $12 \mathrm{~h}, 83 \% \quad \mathrm{NO}_{2}$

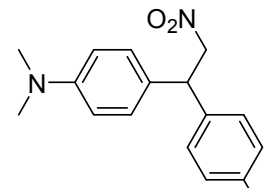

4c, $12 \mathrm{~h}, 77 \%$

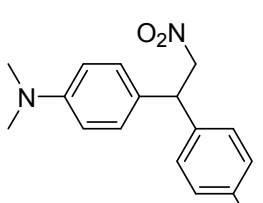

4d, $12 \mathrm{~h}, 79 \% \quad \mathrm{Cl}$

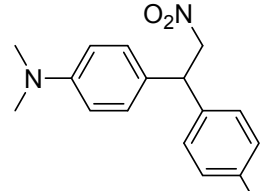

4e, $12 \mathrm{~h}, 81 \% \mathrm{Br}$

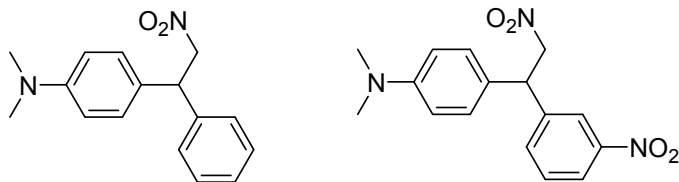

4h, 12 h, $72 \%$<smiles>CN(C)c1ccc(C(C[N+](=O)[O-])c2ccccc2[N+](=O)[O-])cc1</smiles>

$4 i, 12$ h, $45 \%$<smiles>CN(C)c1ccc(C(C[N+](=O)[O-])c2cccs2)cc1</smiles>

4j, 12 h, $68 \%$

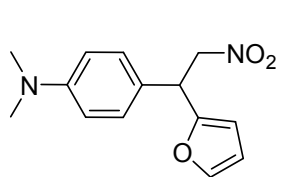

4k, 12 h, $48 \%$

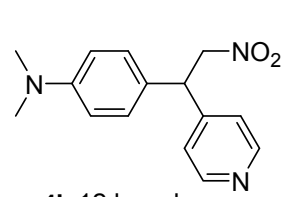

4I, 12 h, n.d.

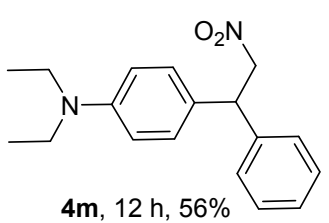

$4 \mathrm{~m}, 12 \mathrm{~h}, 56 \%$

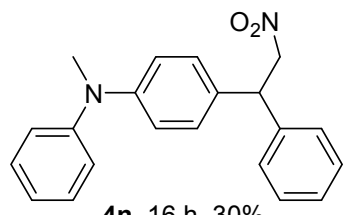

$4 n, 16$ h, $30 \%$

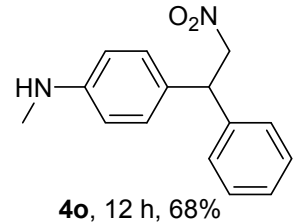

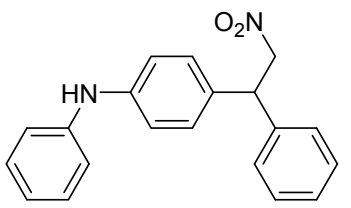

4p, 16 h, $53 \%$

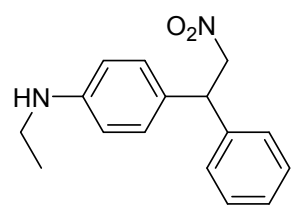

4q, 16 h, $72 \%$

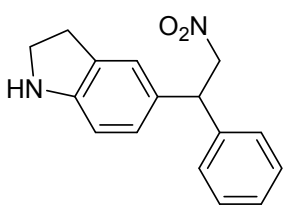

$4 r, 24$ h, $31 \%$

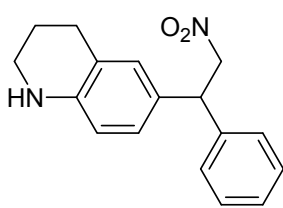

4s, 24 h, $53 \%$

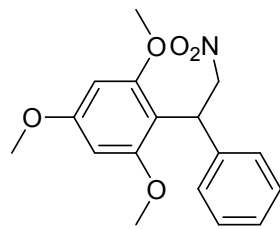

4t, 24 h, $60 \%$

${ }^{a}$ All the reactions were performed by using $\mathbf{1}(0.2 \mathrm{mmol}), \mathbf{2}(0.2 \mathrm{mmol})$ and $\mathbf{3}(0.2 \mathrm{mmol})$ at $60{ }^{\circ} \mathrm{C}$ in DES $\left([\mathrm{ChCl}]\left[\mathrm{ZnCl}_{2}\right]\right)$. Isolated yield after silica gel column chromatograph.

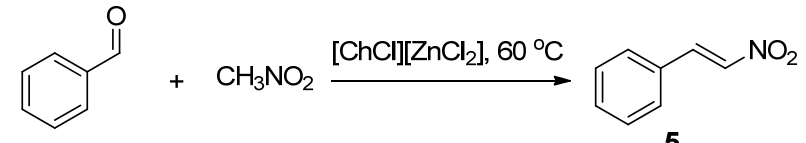

1a $(0.2 \mathrm{mmol}) \quad 2$ (0.2 mmol)
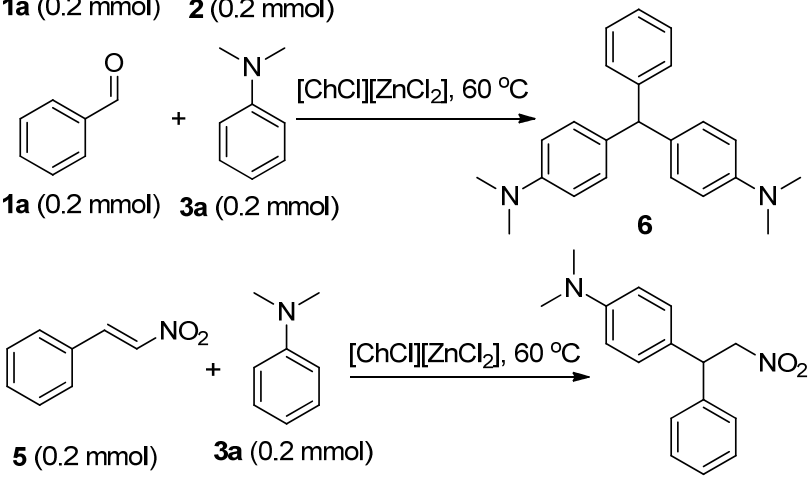

Scheme 2 Control experiments

the aqueous layer. The recycled DES was used for five consecutive runs. The data presented in Figure 2 show that the yield is only slightly reduced after each recycle. Therefore, these results are useful for future industrial applications and environmental protection.

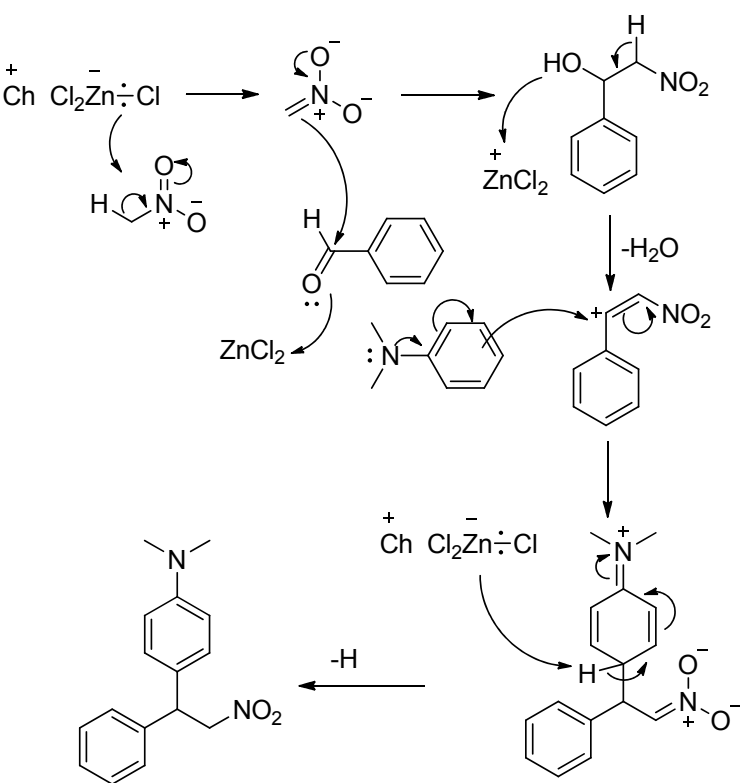

Scheme 3 Proposed mechanism for the reaction 


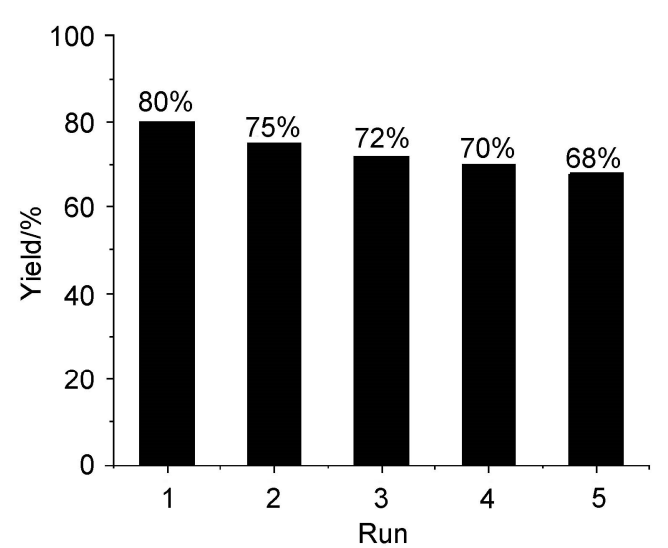

Figure 2 Test of recyclability of $[\mathrm{CholineCl}]\left[\mathrm{ZnCl}_{2}\right]$ reaction

\section{Conclusions}

In conclusion, a novel strategy for one-pot domino Henry/Friedel-Crafts alkylation reaction between aldehydes, nitromethane and $N$-substituted anilines in $[\mathrm{ChCl}]\left[\mathrm{ZnCl}_{2}\right]$ was firstly developed. The desired products were formed smoothly in a short time at a low temperature without any additional catalysts or reagents. In this strategy, aldehydes and nitromethane are used directly as raw materials in one pot, so that $\beta$-nitrosytrene need not be prepared. Besides, mild reaction conditions, simple work-up, non-requirement of additives, and use of a green solvent are the notable advantages of the proposed method, which make it an attractive strategy in the field of organic chemistry.

\section{Experimental section}

\subsection{General procedure for the synthesis of DESs}

\subsubsection{Synthesis of $[\mathrm{ChCl}]\left[\mathrm{ZnCl}_{2}\right]$}

For the preparation of this deep eutectic solvent, a mixture of choline chloride ( $2 \mathrm{mmol}, 0.2792 \mathrm{~g}$ ) and zinc(II) chloride (2 mmol, $0.2726 \mathrm{~g}$ ) was heated to $100{ }^{\circ} \mathrm{C}$ until a clear colorless liquid appeared, then allowed to cool at room temperature and used without further purification.

\subsubsection{Synthesis of $[\mathrm{ChCl}]\left[\mathrm{ZnCl}_{2}\right]_{2}$}

For the preparation of this deep eutectic solvent, a mixture of choline chloride ( $2 \mathrm{mmol}, 0.2792 \mathrm{~g}$ ) and zinc(II) chloride (4 mmol, $0.5452 \mathrm{~g}$ ) was heated to $100{ }^{\circ} \mathrm{C}$ until a clear colorless liquid appeared, then allowed to cool at room temperature and used without further purification. ${ }^{[22]}$

\subsubsection{Synthesis of $[\mathrm{ChCl}]\left[\mathrm{ZnCl}_{2}\right]_{3}$}

For the preparation of this deep eutectic solvent, a mixture of choline chloride ( $2 \mathrm{mmol}, 0.2792 \mathrm{~g}$ ) and zinc(II) chloride (4 mmol, $0.8178 \mathrm{~g}$ ) was heated to $100{ }^{\circ} \mathrm{C}$ until a clear colorless liquid appeared, then allowed to cool at room temperature and used without further purification.

\subsubsection{Synthesis of [ChCl][Urea $]_{2}$}

For the preparation of this deep eutectic solvent, a mixture of choline chloride ( $2 \mathrm{mmol}, 0.2792 \mathrm{~g}$ ) and urea (4 mmol, $0.2402 \mathrm{~g}$ ) was heated to $100{ }^{\circ} \mathrm{C}$ until a clear colorless liquid appeared, then allowed to cool at room temper- ature and used without further purification.

\subsubsection{Synthesis of [ChCl][Glucose]}

For the preparation of this deep eutectic solvent, a mixture of choline chloride ( $2 \mathrm{mmol}, 0.2792 \mathrm{~g}$ ) and glucose (2 mmol, $0.3603 \mathrm{~g}$ ) was heated to $100{ }^{\circ} \mathrm{C}$ until a clear colorless liquid appeared, then allowed to cool at room temperature and used without further purification.

\subsubsection{Synthesis of [ $\mathrm{ChCl}][\mathrm{Citric}$ acid]}

For the preparation of this deep eutectic solvent, a mixture of choline chloride ( $2 \mathrm{mmol}, 0.2792 \mathrm{~g}$ ) and citric acid ( 2 mmol, $0.3842 \mathrm{~g}$ ) was heated to $100{ }^{\circ} \mathrm{C}$ until a clear colorless liquid appeared, then allowed to cool at room temperature and used without further purification.

\subsection{General procedure and characterization for the preparation of $4 \mathrm{a} \sim 4 \mathrm{t}$}

A mixture of nitromethane $(0.2 \mathrm{mmol})$, aromatic aldehyde $(0.2 \mathrm{mmol})$ and electron-rich arenes $(0.2 \mathrm{mmol})$ was stirred in $[\mathrm{ChCl}]\left[\mathrm{ZnCl}_{2}\right]$ at $60{ }^{\circ} \mathrm{C}$ for $12 \mathrm{~h}$. After completion of reaction (monitored through thin-layer chromatography), the mixture was cooled to room temperature, poured into a vessel containing distilled water and then extracted with ethyl acetate $(15 \mathrm{~mL} \times 3)$. The combined organic phase was dried over $\mathrm{Na}_{2} \mathrm{SO}_{4}$. The solvent was then removed. The crude product was then purified by column chromatography using hexane/ethyl acetate as eluent and silica gel 200 300 mesh.

\subsection{General procedure for the synthesis $\beta$-nitro- sytrene}

To a mixture of benzaldehyde $(20 \mathrm{mmol})$ and nitromethane $(20 \mathrm{mmol})$ in methanol $(5 \mathrm{~mL})$ was added a solution of $\mathrm{NaOH}$ in $\mathrm{H}_{2} \mathrm{O}(24 \mathrm{mmol}$ in $2 \mathrm{~mL})$ dropwise at $0{ }^{\circ} \mathrm{C}$. Further methanol $(2 \mathrm{~mL})$ was added and the resulting yellow slurry was stirred at that temperature for $1 \mathrm{~h}$. Water (30 $\mathrm{mL})$ was added and the clear yellow solution was poured into $3 \mathrm{~mol} / \mathrm{L}$ hydrochloric acid and stirred for 15 min. The aqueous mixture was extracted with dichloromethane (DCM) $(20 \mathrm{~mL} \times 3)$, the combined organic layer was dried over anhydrous $\mathrm{Na}_{2} \mathrm{SO}_{4}$ and concentrated in vacuum. The residue was purified by column chromatography using petroleum ether/ethyl acetate as eluant to give desired products. ${ }^{[2 \mathrm{~b}]}$

$N, N$-Dimethyl-4-(2-nitro-1-phenylethyl)aniline $\quad$ (4a) $:^{[9]}$ Yellow liquid, $80 \%$ yield. ${ }^{1} \mathrm{H}$ NMR $\left(500 \mathrm{MHz} \mathrm{CDCl}_{3}\right) \delta$ : $7.32 \sim 7.22(\mathrm{~m}, 5 \mathrm{H}), 7.08(\mathrm{~d}, J=8.7 \mathrm{~Hz}, 2 \mathrm{H}), 6.66(\mathrm{~d}, J=$ $8.8 \mathrm{~Hz}, 2 \mathrm{H}), 4.97 \sim 4.89(\mathrm{~m}, 2 \mathrm{H}), 4.80(\mathrm{t}, J=8.2 \mathrm{~Hz}, 1 \mathrm{H})$, $2.91(\mathrm{~s}, 6 \mathrm{H}) ;{ }^{13} \mathrm{C} \mathrm{NMR}\left(126 \mathrm{MHz}, \mathrm{CDCl}_{3}\right) \delta: 149.85$, $140.00,128.91,128.36,127.59,127.31,126.67,112.77$, $79.66,48.25,40.47$.

$N, N$-Dimethyl-4-(2-nitro-1-(4-nitrophenyl)ethyl)aniline (4b): Yellow liquid, 83\% yield. ${ }^{1} \mathrm{H}$ NMR (500 MHz, $\left.\mathrm{CDCl}_{3}\right) \delta: 8.17(\mathrm{~d}, J=8.8 \mathrm{~Hz}, 2 \mathrm{H}), 7.42(\mathrm{~d}, J=8.7 \mathrm{~Hz}$, 2H), $7.04(\mathrm{~d}, J=8.7 \mathrm{~Hz}, 2 \mathrm{H}), 6.66(\mathrm{~d}, J=12.0 \mathrm{~Hz}, 2 \mathrm{H})$, $5.02 \sim 4.89(\mathrm{~m}, 3 \mathrm{H}), 2.93(\mathrm{~s}, 6 \mathrm{H}) ;{ }^{13} \mathrm{C} \mathrm{NMR}(126 \mathrm{MHz}$, $\left.\mathrm{CDCl}_{3}\right) \delta: 150.15,147.48,147.12,128.52,128.30,124.76$, 124.16, 112.81, 78.85, 47.96, 40.34; HRMS calcd for 
$\mathrm{C}_{14} \mathrm{H}_{18} \mathrm{~N}_{2} \mathrm{O}_{3}[\mathrm{M}+\mathrm{H}]^{+}$316.1292, found 316.1268.

4-(1-(4-(Dimethylamino)phenyl)-2-nitroethyl)benzonitrile (4c): Yellow liquid, $77 \%$ yield. ${ }^{1} \mathrm{H}$ NMR (500 $\left.\mathrm{MHz}, \mathrm{CDCl}_{3}\right) \delta: 7.59$ (d, $\left.J=8.4 \mathrm{~Hz}, 2 \mathrm{H}\right), 7.36(\mathrm{~d}, J=8.3$ $\mathrm{Hz}, 2 \mathrm{H}), 7.03$ (d, $J=8.8 \mathrm{~Hz}, 2 \mathrm{H}), 6.66(\mathrm{~d}, J=8.8 \mathrm{~Hz}, 2 \mathrm{H})$, $4.99 \sim 4.82(\mathrm{~m}, 3 \mathrm{H}), 2.92(\mathrm{~s}, 6 \mathrm{H}) ;{ }^{13} \mathrm{C} \mathrm{NMR}(126 \mathrm{MHz}$, $\left.\mathrm{CDCl}_{3}\right) \delta: 150.11,145.51,132.72,128.43,128.31,124.93$, 118.54, 112.80, 111.31, 78.85, 48.16, 40.36; HRMS calcd. for $\mathrm{C}_{17} \mathrm{H}_{18} \mathrm{~N}_{3} \mathrm{O}_{2}[\mathrm{M}+\mathrm{H}]^{+}$296.1393, found 296.1391.

4-(1-(4-Chlorophenyl)-2-nitroethyl)- $N, N$-dimethylaniline (4d): ${ }^{[9]}$ White solid, 79\% yield. m.p. $62 \sim 65{ }^{\circ} \mathrm{C} ;{ }^{1} \mathrm{H}$ NMR (500 MHz, $\left.\mathrm{CDCl}_{3}\right) \delta: 7.26(\mathrm{t}, J=9.6 \mathrm{~Hz}, 2 \mathrm{H}), 7.16$ $(\mathrm{d}, J=8.4 \mathrm{~Hz}, 2 \mathrm{H}), 7.04(\mathrm{~d}, J=8.8 \mathrm{~Hz}, 2 \mathrm{H}), 6.65$ (d, $J=$ $8.8 \mathrm{~Hz}, 2 \mathrm{H}), 4.93 \sim 4.72(\mathrm{~m}, 3 \mathrm{H}), 2.91(\mathrm{~s}, 6 \mathrm{H}) ;{ }^{13} \mathrm{C} \mathrm{NMR}$ $\left(126 \mathrm{MHz}, \mathrm{CDCl}_{3}\right) \delta: 149.95,138.57,133.19,129.08$, $128.98,128.27,126.03,112.78,79.41,47.63,40.43$.

4-(1-(4-Bromophenyl)-2-nitroethyl)- $N, N$-dimethylaniline (4e): Yellow liquid, 81\% yield. ${ }^{1} \mathrm{H}$ NMR $(500 \mathrm{MHz}$, $\left.\mathrm{CDCl}_{3}\right) \delta: 7.43(\mathrm{~d}, J=8.5 \mathrm{~Hz}, 2 \mathrm{H}), 7.11(\mathrm{~d}, J=8.4 \mathrm{~Hz}$, $2 \mathrm{H}), 7.04(\mathrm{~d}, J=8.7 \mathrm{~Hz}, 2 \mathrm{H}), 6.66(\mathrm{~d}, J=8.8 \mathrm{~Hz}, 2 \mathrm{H})$, $4.93 \sim 4.85(\mathrm{~m}, 2 \mathrm{H}), 4.76((\mathrm{t}, J=8.5 \mathrm{~Hz}, 1 \mathrm{H}), 2.91(\mathrm{~s}, 6 \mathrm{H})$; ${ }^{13} \mathrm{C}$ NMR $\left(126 \mathrm{MHz}, \mathrm{CDCl}_{3}\right) \delta: 149.95,139.08,132.02$, 129.32, 128.26, 125.93, 121.29, 112.77, 79.32, 47.68, 40.11; HRMS calcd for $\mathrm{C}_{16} \mathrm{H}_{17} \mathrm{BrN}_{2} \mathrm{O}_{2} \mathrm{Na}[\mathrm{M}+\mathrm{Na}]^{+}$ 371.0365 , found 371.0361 .

4-(1-(4-Methoxyphenyl)-2-nitroethyl)- $N, N$-dimethylaniline (4f): ${ }^{[9]}$ Yellow liquid, $80 \%$ yield. ${ }^{1} \mathrm{H}$ NMR $(500$ $\left.\mathrm{MHz}, \mathrm{CDCl}_{3}\right) \delta: 7.14(\mathrm{~d}, J=8.6 \mathrm{~Hz}, 2 \mathrm{H}), 7.06(\mathrm{~d}, J=8.7$ $\mathrm{Hz}, 2 \mathrm{H}), 6.83$ (d, $J=8.8 \mathrm{~Hz}, 2 \mathrm{H}), 6.66(\mathrm{~d}, J=8.8 \mathrm{~Hz}, 2 \mathrm{H})$, $4.93 \sim 4.84(\mathrm{~m}, 2 \mathrm{H}), 4.75(\mathrm{t}, J=8.2 \mathrm{~Hz}, 1 \mathrm{H}), 3.76(\mathrm{~s}, 3 \mathrm{H})$, $2.91(\mathrm{~s}, 6 \mathrm{H}) ;{ }^{13} \mathrm{C}$ NMR $\left(126 \mathrm{MHz}, \mathrm{CDCl}_{3}\right) \delta: 158.74$, $149.81,132.05,128.65,128.26,127.04,114.28,112.78$, 79.83, 55.27, 47.53, 40.49.

$N, N$-Dimethyl-4-(2-nitro-1-( $p$-tolyl)ethyl)aniline $\quad(\mathbf{4 g})$ : Yellow liquid, $80 \%$ yield. ${ }^{1} \mathrm{H}$ NMR $\left(500 \mathrm{MHz}, \mathrm{CDCl}_{3}\right) \delta$ : $7.17 \sim 7.01(\mathrm{~m}, 6 \mathrm{H}), 6.65(\mathrm{~d}, J=8.8 \mathrm{~Hz}, 2 \mathrm{H}), 4.94 \sim 4.84$ $(\mathrm{m}, 2 \mathrm{H}), 4.75(\mathrm{t}, J=8.2 \mathrm{~Hz}, 1 \mathrm{H}), 2.89(\mathrm{~s}, 6 \mathrm{H}), 2.29(\mathrm{~s}, 3 \mathrm{H})$; ${ }^{13} \mathrm{C}$ NMR $\left(126 \mathrm{MHz}, \mathrm{CDCl}_{3}\right) \delta: 149.84,137.03,136.96$, $129.60,128.33,127.48,126.98,112.81,79.77,47.93$, 40.51, 21.05; HRMS calcd for $\mathrm{C}_{17} \mathrm{H}_{20} \mathrm{~N}_{2} \mathrm{O}_{2} \mathrm{Na}[\mathrm{M}+\mathrm{Na}]^{+}$ 307.1417 , found 307.1413 .

$N, N$-Dimethyl-4-(2-nitro-1-(3-nitrophenyl)ethyl)aniline (4h): ${ }^{[9]}$ Yellow liquid, $72 \%$ yield. ${ }^{1} \mathrm{H}$ NMR $(500 \mathrm{MHz}$, $\left.\mathrm{CDCl}_{3}\right) \delta: 8.19 \sim 8.00(\mathrm{~m}, 2 \mathrm{H}), 7.60(\mathrm{~d}, J=10.0 \mathrm{~Hz}, 1 \mathrm{H})$, 7.50 (t, $J=7.9 \mathrm{~Hz}, 1 \mathrm{H}), 7.07$ (d, $J=8.7 \mathrm{~Hz}, 2 \mathrm{H}), 6.67$ (d, $J=8.9 \mathrm{~Hz}, 2 \mathrm{H}), 5.05 \sim 4.86(\mathrm{~m}, 3 \mathrm{H}), 2.93(\mathrm{~s}, 6 \mathrm{H}) ;{ }^{13} \mathrm{C}$ NMR (126 MHz, $\left.\mathrm{CDCl}_{3}\right) \delta: 150.14,148.59,142.31$, $133.78,129.93,128.27,124.88,122.52,122.47,112.85$, $78.98,47.87,40.35$.

$N, N$-Dimethyl-4-(2-nitro-1-(2-nitrophenyl)ethyl)aniline (4i): Yellow liquid, 45\% yield. ${ }^{1} \mathrm{H}$ NMR $(500 \mathrm{MHz}$, DMSO) $\delta: 7.91 \sim 7.78(\mathrm{~m}, 2 \mathrm{H}), 7.69$ (t, $J=7.1 \mathrm{~Hz}, 1 \mathrm{H})$, $7.50(\mathrm{t}, J=7.2 \mathrm{~Hz}, 1 \mathrm{H}), 7.15(\mathrm{~d}, J=8.8 \mathrm{~Hz}, 2 \mathrm{H}), 6.65$ (d, $J=8.8 \mathrm{~Hz}, 2 \mathrm{H}), 5.46 \sim 5.13(\mathrm{~m}, 3 \mathrm{H}), 2.84(\mathrm{~s}, 6 \mathrm{H}) ;{ }^{13} \mathrm{C}$ NMR (126 MHz, DMSO) $\delta: 150.12,149.86,134.60$, $133.60,129.40,128.92,128.78,125.65,124.96,112.93$, 78.49, 41.87; HRMS calcd for $\mathrm{C}_{16} \mathrm{H}_{17} \mathrm{~N}_{3} \mathrm{O}_{4} \mathrm{Na}[\mathrm{M}+\mathrm{Na}]^{+}$
338.1111, found 338.1109.

$N, N$-Dimethyl-4-(2-nitro-1-(thiophen-2-yl)ethyl)aniline (4j): ${ }^{[9]}$ Yellow liquid, 68\% yield. ${ }^{1} \mathrm{H}$ NMR $(500 \mathrm{MHz}$, $\left.\mathrm{CDCl}_{3}\right) \delta: 7.23 \sim 7.01(\mathrm{~m}, 3 \mathrm{H}), 7.00 \sim 6.78(\mathrm{~m}, 2 \mathrm{H}), 6.67$ $(\mathrm{d}, J=8.8 \mathrm{~Hz}, 2 \mathrm{H}), 5.04 \sim 4.82(\mathrm{~m}, 3 \mathrm{H}), 2.92(\mathrm{~s}, 6 \mathrm{H}) ;{ }^{13} \mathrm{C}$ NMR $\left(126 \mathrm{MHz}, \mathrm{CDCl}_{3}\right) \delta: 150.16,143.72,128.30$, $126.95,126.18,124.92,124.72,112.68,80.34,44.03$, 40.44 .

4-(1-(Furan-2-yl)-2-nitroethyl)- $N, N$-dimethylaniline (4k): Yellow liquid, 48\% yield. ${ }^{1} \mathrm{H}$ NMR (500 MHz, $\left.\mathrm{CDCl}_{3}\right) \delta: 7.35(\mathrm{dd}, J=1.7,0.7 \mathrm{~Hz}, 1 \mathrm{H}), 7.12$ (d, $J=8.8$ $\mathrm{Hz}, 2 \mathrm{H}), 6.68$ (d, $J=8.8 \mathrm{~Hz}, 2 \mathrm{H}), 6.29(\mathrm{dd}, J=3.2,1.9 \mathrm{~Hz}$, $1 \mathrm{H}), 6.08(\mathrm{~d}, J=2.6 \mathrm{~Hz}, 1 \mathrm{H}), 4.99 \sim 4.71(\mathrm{~m}, 3 \mathrm{H}), 2.92(\mathrm{~s}$, $6 \mathrm{H}) ;{ }^{13} \mathrm{C} \mathrm{NMR}\left(126 \mathrm{MHz}, \mathrm{CDCl}_{3}\right) \delta: 152.97,150.44$, $142.31,128.57,124.19,112.73,110.38,107.03,78.48$, 42.84, 40.45; HRMS calcd for $\mathrm{C}_{14} \mathrm{H}_{17} \mathrm{~N}_{2} \mathrm{O}_{3}[\mathrm{M}+\mathrm{H}]$ 261.1233 , found 261.1230 .

$N, N$-Diethyl-4-(2-nitro-1-phenylethyl)aniline $\quad(\mathbf{4 m}):^{[2 \mathrm{~b}]}$ yellow liquid, $56 \%$ yield. ${ }^{1} \mathrm{H}$ NMR $\left(500 \mathrm{MHz}, \mathrm{CDCl}_{3}\right) \delta$ : $7.32 \sim 7.21(\mathrm{~m}, 5 \mathrm{H}), 7.04(\mathrm{~d}, J=8.8 \mathrm{~Hz}, 2 \mathrm{H}), 6.59(\mathrm{~d}, J=$ $8.8 \mathrm{~Hz}, 2 \mathrm{H}), 4.97 \sim 4.87(\mathrm{~m}, 2 \mathrm{H}), 4.78(\mathrm{t}, J=8.2 \mathrm{~Hz}, 1 \mathrm{H})$, $3.30(\mathrm{q}, J=7.1 \mathrm{~Hz}, 4 \mathrm{H}), 1.12(\mathrm{t}, J=7.1 \mathrm{~Hz}, 6 \mathrm{H}) ;{ }^{13} \mathrm{C} \mathrm{NMR}$ $\left(126 \mathrm{MHz}, \mathrm{CDCl}_{3}\right) \delta: 147.07,140.07,128.85,128.52$, $127.59,127.24,125.38,111.85,79.69,48.23,44.25,12.55$.

$N$-Methyl-4-(2-nitro-1-phenylethyl)- $N$-phenylaniline (4n): ${ }^{[2 b]}$ Light green solid, 30\% yield. m.p. 94 96 ${ }^{\circ} \mathrm{C} ;{ }^{1} \mathrm{H}$ NMR $\left(500 \mathrm{MHz}, \mathrm{CDCl}_{3}\right) \delta: 7.26 \sim 7.15(\mathrm{~m}, 7 \mathrm{H}), 7.03 \sim$ $6.90(\mathrm{~m}, 5 \mathrm{H}), 6.82(\mathrm{~d}, J=11.5 \mathrm{~Hz}, 2 \mathrm{H}), 4.92 \sim 4.84(\mathrm{~m}$, $2 \mathrm{H}), 4.76(\mathrm{t}, J=8.2 \mathrm{~Hz}, 1 \mathrm{H}), 3.20(\mathrm{~s}, 3 \mathrm{H}) ;{ }^{13} \mathrm{C} \mathrm{NMR}(126$ $\left.\mathrm{MHz}, \mathrm{CDCl}_{3}\right) \delta: 148.60,148.34,139.62,130.74,129.34$, $129.00,128.37,127.63,127.49,122.37,121.94,119.19$, 79.48, 48.41, 40.19 .

$N$-Methyl-4-(2-nitro-1-phenylethyl)aniline (4o): ${ }^{[2 b]}$ Light green solid, $68 \%$ yield. m.p. $94 \sim 96{ }^{\circ} \mathrm{C} ;{ }^{1} \mathrm{H}$ NMR $(500$ $\left.\mathrm{MHz}, \mathrm{CDCl}_{3}\right) \delta: 7.32 \sim 7.21(\mathrm{~m}, 5 \mathrm{H}), 7.03(\mathrm{~d}, J=8.5 \mathrm{~Hz}$, $2 \mathrm{H}), 6.54(\mathrm{~d}, J=8.6 \mathrm{~Hz}, 2 \mathrm{H}), 4.97 \sim 4.88(\mathrm{~m}, 2 \mathrm{H}), 4.79(\mathrm{t}$, $J=8.2 \mathrm{~Hz}, 1 \mathrm{H}), 3.71(\mathrm{~s}, 1 \mathrm{H}), 2.79(\mathrm{~s}, 3 \mathrm{H}) ;{ }^{13} \mathrm{C}$ NMR $(126$ $\left.\mathrm{MHz}, \mathrm{CDCl}_{3}\right) \delta: 148.65,139.99,128.91,128.52,127.58$, $127.51,127.32,112.70,79.67,48.34,30.66$.

4-(2-Nitro-1-phenylethyl)- $N$-phenylaniline $(4 p)::^{[2 b]}$ yellow liquid, 53\% yield. ${ }^{1} \mathrm{H}$ NMR $\left(500 \mathrm{MHz}, \mathrm{CDCl}_{3}\right) \delta$ : $7.34 \sim 7.22(\mathrm{~m}, 7 \mathrm{H}), 7.11 \sim 6.91(\mathrm{~m}, 7 \mathrm{H}), 5.68(\mathrm{~s}, 1 \mathrm{H})$, $4.98 \sim 4.91(\mathrm{~m}, 2 \mathrm{H}), 4.83(\mathrm{t}, J=8.2 \mathrm{~Hz}, 1 \mathrm{H}) ;{ }^{13} \mathrm{C} \mathrm{NMR}$ $\left(126 \mathrm{MHz}, \mathrm{CDCl}_{3}\right) \delta: 142.72,142.62,139.59,131.24$, $129.40,129.03,128.64,127.62,127.53,121.43,118.24$, $117.74,79.48,48.42$.

$N$-Ethyl-4-(2-nitro-1-phenylethyl)aniline $\quad(\mathbf{4 q}):^{[2 \mathrm{~b}]}$ Yellow liquid, $72 \%$ yield. ${ }^{1} \mathrm{H}$ NMR $\left(500 \mathrm{MHz}, \mathrm{CDCl}_{3}\right) \delta$ : $7.32 \sim 7.21(\mathrm{~m}, 5 \mathrm{H}), 7.01(\mathrm{~d}, J=8.5 \mathrm{~Hz}, 2 \mathrm{H}), 6.53(\mathrm{~d}, J=$ $8.6 \mathrm{~Hz}, 2 \mathrm{H}), 4.96 \sim 4.86(\mathrm{~m}, 2 \mathrm{H}), 4.78(\mathrm{t}, J=8.2 \mathrm{~Hz}, 1 \mathrm{H})$, $3.53(\mathrm{~s}, 1 \mathrm{H}), 3.10(\mathrm{q}, J=7.1 \mathrm{~Hz}, 2 \mathrm{H}), 1.22(\mathrm{t}, J=7.1 \mathrm{~Hz}$, $3 \mathrm{H}) ;{ }^{13} \mathrm{C} \mathrm{NMR}\left(126 \mathrm{MHz}, \mathrm{CDCl}_{3}\right) \delta: 147.77,140.01$, $128.90,128.55,127.60,127.45,127.31,112.99,79.67$, $48.34,38.42,14.85$.

5-(2-Nitro-1-phenylethyl)indoline $(4 \mathbf{r}):{ }^{[2 b]}$ Gray liquid, $31 \%$ yield. ${ }^{1} \mathrm{H}$ NMR (500 MHz, DMSO) $\delta: 7.37$ (d, $J=7.6$ $\mathrm{Hz}, 2 \mathrm{H}), 7.29$ (t, $J=7.6 \mathrm{~Hz}, 2 \mathrm{H}), 7.20$ (t, $J=7.3 \mathrm{~Hz}, 1 \mathrm{H})$, 
$7.04(\mathrm{~s}, 1 \mathrm{H}), 6.91(\mathrm{~d}, J=8.0 \mathrm{~Hz}, 1 \mathrm{H}), 6.40(\mathrm{~d}, J=8.0 \mathrm{~Hz}$, $1 \mathrm{H}), 5.43(\mathrm{~s}, 1 \mathrm{H}), 5.30 \sim 5.18(\mathrm{~m}, 2 \mathrm{H}), 4.64(\mathrm{t}, J=8.3 \mathrm{~Hz}$, $1 \mathrm{H}), 3.36(\mathrm{t}, J=8.5 \mathrm{~Hz}, 2 \mathrm{H}), 2.83(\mathrm{t}, J=8.4 \mathrm{~Hz}, 2 \mathrm{H}) ;{ }^{13} \mathrm{C}$ NMR (126 MHz, DMSO) $\delta: 152.13,141.71,129.79$, 129.02 , 128.91, 127.95, 127.21, 126.80, 124.04, 108.58, $79.28,48.71,47.02,29.65$.

6-(2-Nitro-1-phenylethyl)-1,2,3,4-tetrahydroquinoline (4s): ${ }^{[2 \mathrm{~b}]}$ Yellow liquid, 53\% yield. ${ }^{1} \mathrm{H}$ NMR (500 MHz, DMSO) $\delta: 7.43 \sim 7.22(\mathrm{~m}, 4 \mathrm{H}), 7.19(\mathrm{t}, J=7.3 \mathrm{~Hz}, 1 \mathrm{H})$, $6.95 \sim 6.72(\mathrm{~m}, 2 \mathrm{H}), 6.33(\mathrm{~d}, J=8.2 \mathrm{~Hz}, 1 \mathrm{H}), 5.59(\mathrm{~s}, 1 \mathrm{H})$, $5.27 \sim 5.13(\mathrm{~m}, 2 \mathrm{H}), 4.57(\mathrm{t}, J=8.3 \mathrm{~Hz}, 1 \mathrm{H}), 3.17 \sim 3.02$ $(\mathrm{m}, 2 \mathrm{H}), 2.59(\mathrm{t}, J=6.3 \mathrm{~Hz}, 2 \mathrm{H}), 1.84 \sim 1.60(\mathrm{~m}, 2 \mathrm{H}) ;{ }^{13} \mathrm{C}$ NMR (126 MHz, DMSO) $\delta$ : 144.87, 141.74, 128.99, $128.67,127.94,127.18,126.82$, 126.09, 120.42, 113.86, 79.26, 48.51, 41.20, 27.21, 21.91 .

1,3,5-Trimethoxy-2-(2-nitro-1-phenylethyl)benzene (4t): ${ }^{[2 \mathrm{~b}]}$ White solid, $60 \%$ yield. m.p. $122 \sim 124{ }^{\circ} \mathrm{C} ;{ }^{1} \mathrm{H}$ NMR (500 MHz, DMSO) $\delta: 7.32 \sim 7.18(\mathrm{~m}, 5 \mathrm{H}), 6.24(\mathrm{~s}$, $2 \mathrm{H}), 5.42 \sim 5.36(\mathrm{~m}, 1 \mathrm{H}), 5.34 \sim 5.30(\mathrm{~m}, 1 \mathrm{H}), 5.23 \sim 5.17$ $(\mathrm{m}, 1 \mathrm{H}), 3.77(\mathrm{~s}, 6 \mathrm{H}), 3.75(\mathrm{~s}, 3 \mathrm{H}) ;{ }^{13} \mathrm{C} \mathrm{NMR}(126 \mathrm{MHz}$, DMSO) $\delta: 160.71,159.02,140.90,128.70,127.80,126.92$, 108.40, 91.90, 78.31, 56.35, 55.68, 38.41.

$\beta$-Nitrosytrene (5): ${ }^{[23]}$ Yellow solid, m.p. $56 \sim 60{ }^{\circ} \mathrm{C} .{ }^{1} \mathrm{H}$ NMR $\left(500 \mathrm{MHz}, \mathrm{CDCl}_{3}\right) \delta: 8.01(\mathrm{~d}, J=13.7 \mathrm{~Hz}, 1 \mathrm{H})$, $7.61 \sim 7.43(\mathrm{~m}, 6 \mathrm{H}) ;{ }^{13} \mathrm{C} \mathrm{NMR}\left(126 \mathrm{MHz}, \mathrm{CDCl}_{3}\right) \delta$ : $139.08,137.15,132.15,129.41,129.15$.

4,4'-(Phenylmethylene)bis $(N, N$-dimethylaniline $) \quad(6)::^{[24]}$ White solid. m.p. $92 \sim 94{ }^{\circ} \mathrm{C}$; ${ }^{1} \mathrm{H}$ NMR $(500 \mathrm{MHz}$, DMSO) $\delta: 7.27(\mathrm{dd}, J=13.6,6.1 \mathrm{~Hz}, 2 \mathrm{H}), 7.17(\mathrm{~d}, J=8.6$ $\mathrm{Hz}, 1 \mathrm{H}), 7.08$ (t, $J=8.0 \mathrm{~Hz}, 2 \mathrm{H}), 6.91$ (dd, $J=15.5,8.7$ $\mathrm{Hz}, 4 \mathrm{H}), 6.66$ (dd, $J=12.0,8.8 \mathrm{~Hz}, 4 \mathrm{H}), 5.31$ (s, 1H), 2.84 $(\mathrm{s}, 12 \mathrm{H}) ;{ }^{13} \mathrm{C}$ NMR (126 MHz, DMSO) $\delta: 149.20,145.85$, $132.68,129.86,129.34,128.53,126.19,112.84,54.66$, 40.74 .

Supporting Information ${ }^{1} \mathrm{H}$ NMR and ${ }^{13} \mathrm{C}$ NMR spectra for all compounds and mass spectra for novel compounds $\mathbf{4 b}, \mathbf{4 c}, \mathbf{4 e}, \mathbf{4 i}$ and $\mathbf{4 k}$. The Supporting Information is available free of charge via the Internet at http://siocjournal.cn.

\section{References}

[1] (a) Bandini, M.; Melloni, A.; Umani-Ronchi, A. Angew. Chem., Int. Ed. 2004, 43, 550 .

(b) Poulsen, T. B.; Jørgensen, K. A. Chem. Rev. 2008, 108, 2903.

(c) You, S.-L.; Cai, Q.; Zeng, M. Chem. Soc. Rev. 2009, 38, 2190.

(d) Terrasson, V.; Marcia de Figueiredo, R.; Campagne, J. M. Eur. J. Org. Chem. 2010, 2635.

(e) Rueping, M.; Nachtsheim, B. J. Beilstein J. Org. Chem. 2010, 6, 6.

(f) Naredla, R. R.; Klumpp, D. A. Chem. Rev. 2013, 113, 6905.

[2] (a) Lancianesi, S.; Palmieri, A.; Petrini, M. Chem. Rev. 2014, 114, 7108 .

(b) Tang, R. J.; Milcent T.; Crousse, B. RSC Adv. 2018, 19, 10314.

[3] Hayashi, T.; Senda, T.; Ogasawara, T. J. Am. Chem. Soc. 2000, $122,10716$.

[4] (a) Saxty, G.; Woodhead, S. J.; Berdini, V.; Davies, T. G.; Verdonk, M. L.; Wyatt, P. G.; Boyle, R. G.; Barford, D.; Downham, R.; Garrett, M. D.; Carr, R. A. J. Med. Chem. 2007, 50, 2293. (b) Burgey, C. S.; Paone, D. V.; Shaw, A. W.; Deng, J. Z.; Nguyen, D. N.; Potteiger, C. M.; Graham, S. L.; Vacca, J. P.; Williams, T. M. Org. Lett. 2008, 10, 3235 .

[5] (a) Zhu, J. P.; Bienaymé, H. Multicomponent Reactions, John Wiley \& Sons, Germany, 2006.

(b) Dömling, A. Chem. Rev. 2006, 106, 17.

[6] (a) Nicolaou, K. C.; Chen, J. S. Chem. Soc. Rev. 2009, 38, 2993.

(b) Touré, B. B.; Hall, D. G. Chem. Rev. 2009, 109, 4439.

(c) Yadav, D. K.; Patel, R.; Srivastava, V. P.; Watal, G.; Yadav, L. D. S. Tetrahedron Lett. 2010, 51, 5701.

[7] Oikawa, Y.; Hirasawa, H.; Yonemitsu, O. Tetrahedron Lett. 1978, 19, 1759.

[8] (a) Paras, N. A.; MacMillan, D. W. S. J. Am. Chem. Soc. 2002, 124, 7894.

(b) Guo, Y. C.; Li, D. P.; Li, Y. L.; Wang, H. M.; Xiao, W. J. Chirality 2009, 21, 777.

(c) Zhou, Y.; Li, X.; Hou, S.; Xu, J. J. Mol. Catal. A: Chem. 2012, $365,203$.

(d) Yin, W.; Ma, Y.; Xu, J.; Zhao, Y. J. Org. Chem. 2006, 71, 4312. (e) Wang, X.; Wang, Y.; Du, D. M.; Xu, J. J. Mol. Catal. A: Chem. 2006, 255, 31 .

(f) Zhang, Z.; Ma, Y.; Zhao, Y. Synlett 2008, 1091.

(g) Xu, J.; Xia, J.; Lan, Y. Synth. Commun. 2005, 35, 2347.

[9] Halimehjani, A. Z.; Farvardin, M. V.; Zanussi, H. P.; Ranjbari, M. A.; Fattahi, M. J. Mol. Catal. A: Chem. 2014, 381, 21.

[10] (a) Ruß, C.; König, B. Green Chem. 2012, 14, 2969.

(b) Zhang, Q.; Vigier, K. D. O.; Royer, S.; Jerome, F. Chem. Soc. Rev. 2012, 41, 7108.

(c) del Monte, F.; Carriazo, D.; Serrano, M. C.; Gutierrez, M. C.; Ferrer, M. L. ChemSusChem 2014, 7, 999.

[11] Xie, Z. B.; Li, H. X.; Liu, Y. S.; Lan, J.; Hu, Z. Y.; Le, Z. G. Chin. J. Org. Chem. 2019, 39, 2632 (in Chinese).

(谢宗波，李红霞，刘联胜，兰金，胡智宇，乐长高，有机化学， 2019, 39, 2632.)

[12] (a) Abbott, A. P.; Capper, G.; Davies, D. L.; Rasheed, R. K. Tambyrajah, V. Chem. Commun. 2003, 70.

(b) Abbott, A. P.; Boothby, D.; Capper, G.; Davies, D. L.; Rasheed, R. K. J. Am. Chem. Soc. 2004, 126, 9142

(c) Carriazo, D.; Serrano, M. C.; Gutierrez, M. C.; Ferrer, M. C.; del Monte, F. Chem. Soc. Rev. 2012, 41, 4996.

[13] Santi, V. D.; Cardellini, F.; Brinchi, L.; Germani, R. Tetrahedron Lett. 2012, 53, 5151.

[14] Azizi, N.; Manocheri, Z. Res. Chem. Intermed. 2012, 38, 1495.

[15] Cristian, V.; Francisco, J. S.; Joaquín, G. A. Catal. Commun. 2014, 44,76 .

[16] Morales, R. C.; Tambyrajah, V.; Jenkins, P. R.; Davies, D. L.; Abbott, A. P. Chem. Commun. 2004, 158.

[17] Sonawane, Y. A.; Phadtare, S. B.; Borse, B. N.; Jagtap, A. R.; Shankarling, G. S. Org. Lett. 2010, 12, 1456.

[18] Friedel, C.; Crafts, J. M. J. Chem. Soc. 1877, 32, 725.

[19] Chen, G. Q.; Xie, Z. B.; Ai, F.; Chen, Z. S.; Lan, J.; Hu, Z. Y.; Le, Z. G. Heterocycles 2019, 98, 1189.

[20] (a) Gao, G.; Wang, P.; Liu, P.; Zhang, W.; Zhang, Z. Chin. J. Org. Chem. 2018, 38, 846 (in Chinese).

(高歌, 王萍, 刘鹏, 张卫红, 默丽萍, 张占辉, 有机化学, 2018, 38,846 .)

(b) Chen, G. Q.; Xie, Z. B.; Liu, Y. S.; Meng, J.; Le, Z. G. Chin. J. Org. Chem. 2020, 40, 156 (in Chinese).

(陈国庆，谢宗波，刘一帅，孟佳，乐长高，有机化学， 2020，40, 156.)

(c) Xiong, X. Q.; Han, Q.; Si, L.; Xiao, S. Y.; Bi, C. Chin. J. Org. Chem. 2016, 36, 480 (in Chinese).

(熊兴泉, 韩寒, 石霖, 肖上运, 毕成, 有机化学, 2016, 36, 480.) (d) Zhang, M.; Liu, T. H.; Shang, Z. R.; Hu, H. C.; Zhang, Z. H. Catal. Commun. 2017, 88, 39.

(e) Liu, P.; Hao, J. W.; Mo, L. P.; Zhang, Z. H. RSC $A d v .2015,5$, 48675 .

(f) Zhang, M.; Liu, P.; Shang, Z. R.; Hu, H. C.; Zhang, Z. H. RSC 
Adv. 2016, 6, 106160

(g) Zhang, W. H.; Chen, M. R.; Hao, Y.; Jian, X.; Zhou, X. L.; Zhang, Z. H. J. Mol. Liq. 2019, 278, 124

(h) Ma, C. T.; Liu, P.; Wu, W.; Zhang, Z. H. J. Mol. Liq. 2017, 242, 606.

[21] Singh, B. S.; Lobo, H. R.; Shankarling, G. S. Catal. Commun. 2012, 24,70 .

[22] (a) Zhang, Y. Y.; Lu, X. H.; Feng, X.; Shi, Y. J.; Ji, X. Y. Prog. Chem. 2013, 25, 881 (in Chinese)

(张盈盈, 路小华, 冯新, 史已俊 吉晓燕, 化学进展, 2013, 25, 881.) (b) Duan, Z.; Gu, Y.; Deng, Y. Catal. Commun. 2006, 7, 651.

(c) Tao, L.; Deng, Y. F.; Gan, S. C.; Chen, J. Chin. J. Chem. Eng. 2010, 18, 322 (in Chinese)

(龙涛, 邓岳锋, 甘树才, 陈继，中国化学工程学报，2010，18, 322.)

(d) Inaloo, I. D.; Majnooni, S.; Esmaeilpour, M. Eur. J. Org. Chem. 2018, 26, 3481.

[23] Zarei, M.; Noroozizadeh, E.; Moosavi-Zare, A. R.; Zolfigol, M. A. J. Org. Chem. 2018, 83, 3645.

[24] Mukhopadhyay, C.; Tapasw, P. K. Synth. Commun. 2012, 42, 2453.

(Zhao, C.) 